\title{
WEB TECHNOLOGY: A TOOL FOR SOCIAL NETWORKING AND RESOURCE SHARING KNOWLEDGE INDICATORS TOWARDS COMMUNITY DEVELOPMENT
}

\author{
${ }^{*}$ Prof. Dr V. KASIRAO, R. SANTHA KUMAR** and Prof. Dr. M. RENGARAJ***
}

\begin{abstract}
Web Technology plays a vital role in library, information and documentation knowledge resource centres and as tool for social networking and resource sharing knowledge indicators towards community development. The Information Communication Technologies (ICTs) serve as a tool for knowledge indicators in Knowledge Organization Management for e-knowledge dissemination and access to service providers (i.e. Governments/Institutions) and service receivers (i.e. community people) for socio economic development. The social network programmes such as e-governance, e-communities, e-culture, e-health, e-business, e-learning etc. are promoting through ICTs applications for rural community development. In view of this, the present paper is related to the paper theme literature analysis on web under study. Outlines the information scientist's effective role in content analysis and content management for knowledge dissemination for access towards community development. This paper emphasizes the need for knowledge access and sharing initiatives for rural community development. Highlights the key issues in relation to ICTs application sources in development context. Provides the guidelines for issues to consider developing the ICTs polices and implementation strategies for socio, economic and cultural development in the present knowledge based society.
\end{abstract}

Keywords: Web Technology, social networking and resource sharing, Knowledge Organization Management, e-knowledge dissemination and access and community development.

${ }^{*}$ Documentation Officer/ Scientist Ell and Head, Documentation Department, Council of Scientific and Industrial Research (CSIR), Central Leather

Research Institute, Adyar, Chennai - 600020. India.

E-mail:v_kasirao@yahoo.com

${ }^{* *}$ Research Associate, Central Institute of Brackishwater Aquaculture,

Raja Annamalai Puram, Chennai- 600028.

${ }^{* * *}$ Principal, Christ College of Education, Nandhimedu Road, Kandoor post, Pannur via,. Kanchipuram District- 602108, India. 


\section{INTRODUCTION}

Web Technology plays a vital role in library, information and documentation knowledge resource centres and as tool for social networking and resource sharing knowledge indicators towards community development. The Information Communication Technologies (ICTs) serve as a tool for knowledge indicators in Knowledge Organization Management for e-knowledge dissemination and access to service providers (i.e. Governments/Institutions) and service receivers (i.e. community people) for socio economic development. The social network programmes such as e-governance, e-communities, e-culture, e- health, e-business, e-learning etc. are promoting through ICTs applications for rural community development.

\section{REVIEW OF LITERATURE}

The review of web- technology literature reveals a number of information resources such as case studies/research work papers, reports, databases, conference proceedings etc. in relation to "web technology: a tool for social networking and resource sharing knowledge indicators towards community development" aspects in the recent years. The present paper presents one such study, which has been carried out by searching the sources on the paper theme aspects.

\section{DEFINITIONAL ANALYSIS}

The paper theme related value added definitional analysis as indicated in Table 1.

Table - 1: Definition Analysis

\begin{tabular}{|c|l|}
\hline S. & \multicolumn{1}{|c|}{ Definition analysis parts/ concepts } \\
No. & $\begin{array}{l}\text { Open source access: The concept "open source" may be defined by Kasi Rao as the Scholarly } \\
\text { communication that is made available to the information user community at free of cost and without } \\
\text { any copy right issues for the purpose of academic and research studies }\end{array}$ \\
\hline 2 & $\begin{array}{l}\text { Social Software: Social software encompasses a range of software system that allows the users to } \\
\text { interact and share data. This computer mediator communication has become very popular with social } \\
\text { sites like Myspace, Facebook etc }\end{array}$ \\
\hline 3. & $\begin{array}{l}\text { E-Knowledge Management skills: E-Knowledge management skills may be defined as the } \\
\text { information handling techniques such as acquisition, storage and control involved for knowledge } \\
\text { dissemination and utilization of e-information product and services in knowledge resource centers } \\
\text { towards organizational development }\end{array}$ \\
\hline 4. & $\begin{array}{l}\text { e-learning: the concept e-learning may be defined as a source of knowledge indicators towards } \\
\text { decision making support and e-learning and education to prepare curriculum for manpower } \\
\text { development towards socio economic development in the present network/digital knowledge society }\end{array}$ \\
\hline
\end{tabular}




\begin{tabular}{|c|l|}
\hline 5. & $\begin{array}{l}\text { Information and Documentation Management : The term Information and Documentation } \\
\text { Management may be defined as the information handling techniques such as acquisition, storage } \\
\text { and control involved for knowledge dissemination and utilization of e- e-e-e- knowledge information } \\
\text { resources in library and information centers for the purpose of organisational development }\end{array}$ \\
\hline 6 & $\begin{array}{l}\text { Knowledge Organization Management (KOM): The term Knowledge Organization Management is the } \\
\text { process of identification; leverage of organization knowledge asserts to deliver to innovative R \& D } \\
\text { supporting sources including business advantage based information sources to the organization and } \\
\text { its customers /user community. In view of this, it is to emphasize that there has been a paradigm shift } \\
\text { in organization from on "Information based organization to knowledge based organization". }\end{array}$ \\
\hline 7. & $\begin{array}{l}\text { Planning Strategies: The term Planning Strategies may be defined as the process of planning for } \\
\text { strategies in information management products and services towards organizational development in } \\
\text { digital environment }\end{array}$ \\
\hline 8. & $\begin{array}{l}\text { Social networking and resource sharing: The term may be defined as the source of knowledge and } \\
\text { access to Knowledge indicators for socio, economics and cultural development in the present } \\
\text { knowledge based society. }\end{array}$ \\
\hline
\end{tabular}

Social networking and resource sharing: The term may be defined as the source of knowledge and access to Knowledge Indicators for socio, economic and cultural development in the present knowledge based society.

\section{SCOPE AND OBJECTIVES:}

The scope of the present paper is significant in the following respects:

* To identify the vital role of information officers in information management for Open Source Access (OSA) facilities in the information knowledge resource centers for societal development

* To provide knowledge awareness to the information seekers on e-information products and services towards community development

* To emphasize the need for Knowledge Access and Sharing Initiatives for Rural Areas Organisation (KASIRAO) towards rural sustainable development in the ICTs Environment

* To emphasize the need for IT application tools for information handling services towards organizational / community development

* To identify the Knowledge Organization Management Skills (KOMS) for einformation products and services towards orgnisational/community development

\section{METHODOLOGY ADOPTIONS}

Web knowledge resources served as a tool for data collections, analysis and interpretation for this present paper study. 


\section{LIMITATIONS}

The limitation of the study is confined in relation to the present paper theme study on "web technology: a tool for social networking and resource sharing knowledge indicators towards community development".

\section{ELECTRONIC COMMUNICATION TOOLS AND COMMUNITY DEVELOPMENT}

Electronic communication tools are very useful to send messages, files, data or documents between people and media of communication sources to facilitate knowledge sharing of information. Examples are specified below:

- synchronous conferencing

- asynchronous conferencing

- e-mail

- faxing

- voice mail

- Web publishing etc

\section{ELECTRONIC CONFERENCING TOOLS}

Electronic conferencing tools facilitate the sharing of information in an interactive way towards community development. The communication tools are highlighted below:

- Internet forums (also known as message boards or discussion boards) - a virtual discussion platform to facilitate and manage online text messages

- Online chat - a virtual discussion platform to facilitate and manage real-time text messages

- Instant Messaging

- Telephony - telephones allow users to interact

- Videoconferencing - networked PCs share video and audio signals

- Data conferencing - networked PCs share a common whiteboard that each user can modify

- Application sharing - users can access a shared document or application from their respective computers to acquire knowledge according to their requirements

- Electronic meeting systems (EMS) meant for special purpose meeting rooms usually contained video projectors interlinked with numerous PCs; and have evolved into web-based, any time, any place systems that will accommodate "distributed" meeting participants for dispersed purpose in several locations 


\section{WEB 2.0 AND SOCIAL SOFTWARE}

Web 2.0 and social software encompass technologies that allow individuals to interact with other people to build the networking and resource sharing facilities on professional development aspects. Some of the social software technology sources are indicated below:

- Wikis

- Blogs

- Social Networking

- Social Bookmarking

- Micro blogging

- Instant Messaging

- Photo Sharing

- Video Sharing

\section{TYPES OF WEB KNOWLEDGE INDICATORS AND COMMUNITY DEVELOPMENT}

Table 2 provides the information in relation to web knowledge indicators and community development

Table - 2: Web knowledge indicators and community development

\begin{tabular}{|c|l|l|}
\hline S. No & \multicolumn{1}{|c|}{ Types of web knowledge sources } & \multicolumn{1}{|c|}{ Types of Knowledge indicators } \\
\hline 1 & http:// en.wikipedia.org & Access to social networking and resource sharing \\
\hline 2 & http://epp.eurostat.ec.europa.eu & $\begin{array}{l}\text { Access to statistical information knowledge } \\
\text { sources }\end{array}$ \\
\hline 3 & http://www.systems-thinging.org & Access to knowledge management \\
\hline 4 & http://users.cio.com & Access to business management \\
\hline 5 & http://www.nelh.nhs.uk & $\begin{array}{l}\text { Access to knowledge management in health } \\
\text { information }\end{array}$ \\
\hline 6 & http://wiki.nasa.gov & Access to online information management \\
\hline 7 & http://wordpress.org & $\begin{array}{l}\text { Access to knowledge management in community } \\
\text { related forums }\end{array}$ \\
\hline 8 & http://blog,aidsportal.org & $\begin{array}{l}\text { Access to global knowledge network on health } \\
\text { related information resources }\end{array}$ \\
\hline 9 & http://www.peep.com & $\begin{array}{l}\text { Access to networking related information } \\
\text { resources }\end{array}$ \\
\hline 10 & http://www.jugand.in & $\begin{array}{l}\text { Access to knowledge management in software } \\
\text { communication tools }\end{array}$ \\
\hline
\end{tabular}




\section{INFORMATION OFFICERS/ SCIENTISTS ROLE IN INFORMATION MANAGEMENT PRODUCTS AND SERVICES}

The information scientists play a vital role in Information and Documentation Centers (IDCs) and as an information facilitator for access to the value added eknowledge information products and services towards organizational development. The Knowledge Organization Management Skills (KOMS) and the information officer's role as identified in relation to knowledge management on information product and services. The value added concept analysis in relation to knowledge management towards information products and services as indicated in Fig. 1

The value added concept analysis in relation to knowledge management in information products and services:

Figure -1: Information scientists role in Information Processing stages on Information Products and Services

- Decision Making/ Knowledge supporting/ Dissemination Stage

- Synthesizing

- Analysizing

- Summarising

- Processing

- Collecting

- Scanning/

- Accessin

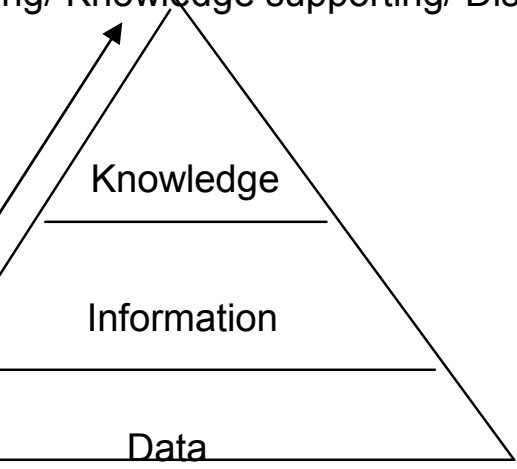

\section{NEED FOR KNOWLEDGE ACCESS AND SHARING INITIATIVES FOR RURAL}

\section{AREAS ORGANISATION (KASIRAO) FOR RURAL SUSTAINABLE}

\section{DEVELOPMENT}

Based on the Author's (KasiRao) innovative concept knowledge identity theory titled on "Knowledge Access and Sharing Initiatives for Rural Areas Organisation (KASIRAO)", the author has also identified and developed the new innovative formula concept known as $\mathrm{K}=6 \mathrm{~A}$ to support its theory on KASIRAO towards rural sustainable development in the present digital age. The theory and its formula as highlighted below in Fig: 2 
Figure -2: Knowledge Access and Sharing Initiatives for Rural Areas Organisation (KASIRAO). The new Social Development theory and its Formula as a tool for conceptual analysis view

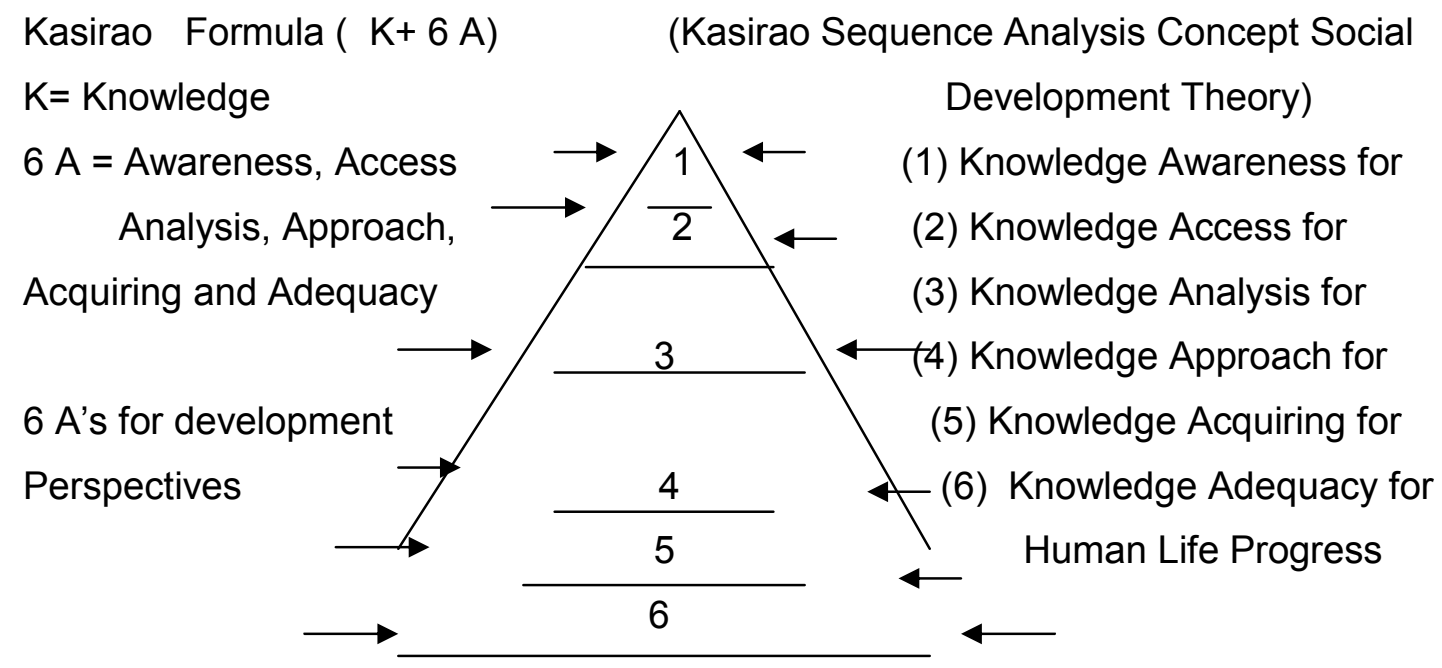

Knowledge indicators towards rural sustainable development in ICTs environment.

\section{ISSUES AND STRATEGIES RELATED KNOWLEDGE INDICATORS TOWARDS COMMUNITY DEVELOPMENT: AN INDIAN SCENARIO}

The issues and strategies are indicated in Table- 3

Table - 3: The issues and strategies

\begin{tabular}{|c|l|l|}
\hline S. No & \multicolumn{1}{|c|}{ Issues } & \multicolumn{1}{c|}{ Planning Strategies } \\
\hline 1 & $\begin{array}{l}\text { Lack of awareness and access to } \\
\text { information on social participation, } \\
\text { public health, education, pollution } \\
\text { control, environmental planning } \\
\text { impact etc. and lack of awareness } \\
\text { on information system and services } \\
\text { available in IDCs in relation to social } \\
\text { networking and resource sharing } \\
\text { towards community development }\end{array}$ & $\begin{array}{l}\text { Creating knowledge awareness to the rural people } \\
\text { and access to the e- knowledge information } \\
\text { resources in relation to pollution free/fresh drinking } \\
\text { water, poverty eradication, social health education, } \\
\text { livelihoods and food security for sustainable } \\
\text { development in the present Global Climate } \\
\text { Changing Environment }\end{array}$ \\
\hline 2 & $\begin{array}{l}\text { III-developed information institutions } \\
\text { actions }\end{array}$ & $\begin{array}{l}\text { Establishing a need based well structured } \\
\text { information resource center in the modern lines in } \\
\text { academic and research institutions to access with } \\
\text { knocial networking and resource sharing related e- } \\
\text { towards community development }\end{array}$ \\
\hline 3 & $\begin{array}{l}\text { Lack of manpower planning in } \\
\text { Human resource development }\end{array}$ & $\begin{array}{l}\text { Man power planning is essential towards Human } \\
\text { Resource Development (HRD) to provide IT based } \\
\text { information product and services in academic, R\&D }\end{array}$ \\
\hline
\end{tabular}




\begin{tabular}{|c|l|l|}
\hline & & and other similar service oriented institutions \\
\hline 4 & $\begin{array}{l}\text { Lack of education and training in } \\
\text { web knowledge management in } \\
\text { library, information and } \\
\text { documentation knowledge resource } \\
\text { centers }\end{array}$ & $\begin{array}{l}\text { Web learning education and training is essential to } \\
\text { overcome the issues in teaching, Organization of } \\
\text { distance education, Web based syllabi preparation } \\
\text { in handling classes and web learning management } \\
\text { in Audio and video conferencing }\end{array}$ \\
\hline 5 & $\begin{array}{l}\text { Lack of funding facilities in IT } \\
\text { enhanced knowledge organization } \\
\text { management resources and } \\
\text { services }\end{array}$ & $\begin{array}{l}\text { Adequate funding facilities both from central and } \\
\text { state governments and the funding facilities from e- } \\
\text { learning projects etc are essential to manage web } \\
\text { based learning cost and organizational issues and } \\
\text { provide efficient and effective services to the } \\
\text { library user community }\end{array}$ \\
\hline 6 & $\begin{array}{l}\text { Political strategy } \\
\text { Political strategy is essential factor for funding } \\
\text { mobilization and its regulations in information } \\
\text { management system and services as well as in } \\
\text { social capital resource management towards rural } \\
\text { community sustainable development }\end{array}$ \\
\hline 7 & $\begin{array}{l}\text { Lack of collective approach for } \\
\text { decision making policy in social } \\
\text { networking and resource sharing } \\
\text { management }\end{array}$ & $\begin{array}{l}\text { The collective approach is essential for decision } \\
\text { making policy in social capital for good } \\
\text { governance and adequate mechanism in social } \\
\text { capital resources management process for rural } \\
\text { community development }\end{array}$ \\
\hline
\end{tabular}

\section{CONCLUSION}

The Web technology plays a vital role for information management knowledge indicators in relation to social networking and resource sharing towards societal development. The ICTs serve as a tool for decision-making policy support in relation to information management issues towards the provision of information product and services in digital environment. The changing scenario of Information and communication technologies, the information officers shall strive for digital knowledge organization management skills in library, information and documentation knowledge resource centers to provide the need based information services to the information user community in an effective manner in the knowledge based society.

\section{REFERENCES}

[1]. Kasirao, V and Shella devi, K (2006). Open Source Access a tool for organization development. IASLIC National conference, IIT, Roorkee, 13-16 December, 2006: 7882

[2]. Kasirao, V. (2007). E-Knowledge Organization Management Skills (EKOMS): A tool for organizational development. Paper presented in the CLRI foundations day celebrations national conference on $24^{\text {th }}$ April, 2007

[3]. Kasirao, V. (2007). E-knowledge Management: A tool for organizational development. Paper presented in the International Conference on Information Technology 
Management (ICITM-2007) held at Hong Kong Polytechnic University, Hong Kong from 3-5 January, 2005

[4]. Kasi rao, V. (2006) IPR: A tool for organizational Development paper accepted for presentation in the International conference on Information Society (IS) held at Miami University Florida, USA during 7-10, August 2006.

[5]. KasiRao, V. (2007). ICTs: A tool for Knowledge Organisation Management Skills(KOMS) in information Products and Services(IPS) for organisational development. Paper presented in the National conference on Knowledge Organisation Management Skills(KOMS), held at Bishop Heber College, Tiruchirapalli, from 23-24,

February,2007.

[6]. Kasirao, V(2007) Web Technology Knowledge indicators in Environment Impact Assessment (EIA): A tool for Water Resources Management (WARM) Industry for sustainable development. IN: International conference Proceedings on Environment Management Scenario and Strategies EMASS -2020 held at Ujjain Engineering College, Ujjain, Madhya Pradesh from 26-27 December 2007:26-31.

[7]. Kasi rao, V. (2007). Information and Communication Technologies (ICTs): A Tool for Water Resources Management (WARM) in Industry for sustainable development. $\underline{I N}$

World Water Week (WWW) Conference proceedings held at Stockholm International Water Institute (SIWI), Sweden $12-18^{\text {th }}$ August :182

[8] Kumar, O .B, and Sreenivasa Reddy, V. (2003). Digital Library Use: A case study of NIT Library, Wrangle. ILA Bulletin, 39 (2), 40- 45.

[9]. http://www.google.co.in

[10]. http://www.nicair.res.in

[11]. http://www.iimad.ernet.in

[12]. http://www.clri.org

[13]. http://www.infla.org

[14]. http://www.siwi.org

[15]. http://www.world water week.org 